\title{
IDENTIFICATION OF NOISE GENERATED BY DRIVING SET OF AUTOGYRO USING AN ACOUSTIC CAMERA
}

\author{
Paweł Magryta', Krzysztof Skiba' ${ }^{1}$ Zbigniew Czyż \\ 1 Lublin University of Technology, Faculty of Mechanical Engineering, Department of Thermodynamics, Fluid \\ Mechanics and Aviation Propulsion Systems Lotniczych, 36 Nadbystrzycka St., 20-618 Lublin, Poland, e-mail: \\ p.magryta@pollub.pl, k.skiba@pollub.pl, z.czyz@pollub.pl
}

Received: 2017.10 .24

Accepted: 2017.11.01

Published: 2017.12.05

\begin{abstract}
The article discusses the advantages of using an acoustic camera to analyze noise distribution. Location of noise sources was based on example of an autogyro model. Tests were performed using a 16-microphone acoustic camera using Noise Inspector software. Acoustic maps and sound power levels for two aircraft operations conditions were obtained. The results obtained during the various states of the model work were compared.
\end{abstract}

Keywords: autogyro, noise, acoustic camera, Noise Inspector software.

\section{INTRODUCTION}

Among the existing aircrafts, the future direction is now attributed to autogyros, but the same principles of design and operation, do not make them modern and innovative aircrafts. The creation of an unrivaled machine, with excellent performance and a wide field of applications on an autogyro basis is possible, provided the basic structure to be complemented by additional systems and equipment that will give the features that have not been used by aircrafts so far. First of all, it is necessary to allow the autogyro to perform vertical take-off and hover. Another important criterion is the achievement of high cruise speeds, while maintaining noise emissions from the drive units at relatively low levels. The realization of the above assumptions allows for the construction of a aircraft that exceeds the capabilities of helicopters, as well as being unrivaled for other aircrafts [7]. In pursuit of the development of modern flying machines, more and more attention is paid to their environmental impact. The results presented in this article are part of the work aimed at the development of autogyros also in the context of reducing noise emissions. As de- scribed in the literature, the three most important environmental factors in the field of air transport are emission of toxic pollutants, noise and fuel consumption $[11,12,17]$. Noise is generated by all sorts of aircraft sets, and in particular by propulsion systems. This is most noticeable during the take-off procedure when the engine is running at its maximum power. Research works are also being carried out to reduce turbojet engine noise by modifying the nozzles, what was described in [18]. The COSMA (Community Oriented Solutions to Minimize Aircraft Noise Annoyance) project under the 7th Framework Program of the European Commission was also implemented in the scope of noise reduction in 2009-2013. The project was aimed at learning about the impact of aircraft noise on the society in the airports area $[2,3,4,5,6]$.

\section{ACOUSTIC CAMERA AND NOISE INSPECTOR SOFTWARE}

The measurement method that was used, consisted of noise sources location using the Noise Inspector software and acoustic camera from 
CAE Systems \& Software company. This equipment allows to convert sound into an image or video. As a result, sound sources become visible and can be easily localized [13]. With such a visualization, it is possible to quickly locate the sound source in real time. The system is capable of locating the sound as well as measuring its intensity (emitted sound pressure). The visualization of a sound source in a photo or video, allows for a reduction in measurement time, in comparison to traditional, time-consuming and costly methodologies [13]. The system consists of a microphone array equipped with 16 microphones, in which, a HD camera is located in the central point, in addition to the system, modules for signal processing and image are attached (Figure 1). The whole system is connected to a portable computer. The microphone arrangement is in one $\mathrm{Z}$ plane. Microphones are one directional, and measurements are made in a direction perpendicular to the plane of the array $[9,10]$.

Components of the Noise Inspector system:

- microphone array,

- HD camera Microsoft LifeCam Studio 1080p,

- 16 one dimensional microphones G.R.A.S. $40 \mathrm{PH}$,

- ICP data acquisition module with accessories PXIe-1073 from National Instruments,

- PXI card 4496 measuring card,

- portable computer,

- CAE Noise Inspector V6.0 software.

The measurement method used is very convenient. The Noise Inspector system is a modular and highly flexible solution that allows to match the device to specific needs. Among the many advantages of an acoustic camera, those below can be mentioned:

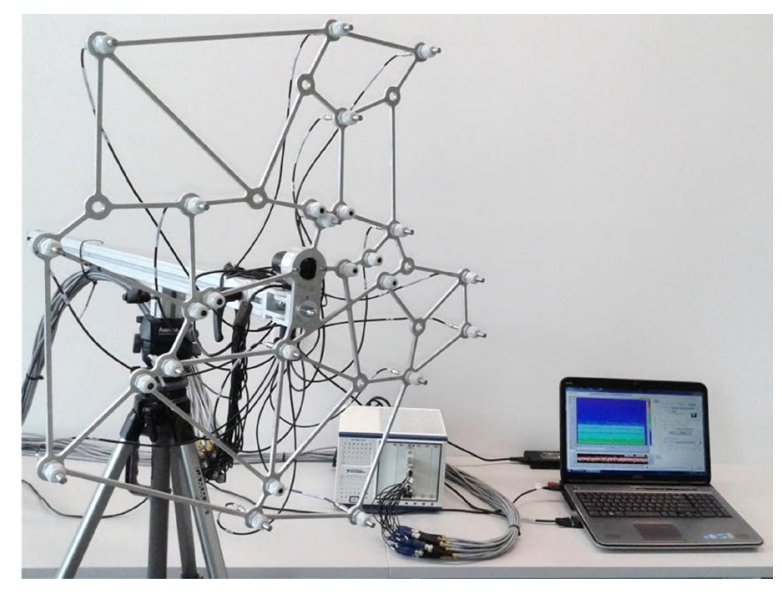

Fig. 1. Acoustic camera (own study)
- only one measurement instead of many is needed,

- result of the measurement of the acoustic camera is much more accurate than the classical measuring microphone,

- system does not interfere with the operation of the equipment during measurement (e.g. in factories, production halls),

- measurement lasts only a few minutes,

- as a result of the measurement, we obtain a map of sources generating unwanted noise,

- we are able to determine which elements of a given system generate noise and what is the level of that noise,

- there is no need to stop work, at the measuring site,

- it is possible to identify noise sources even in the reverberation environment,

- indoor and outdoor measurements can be made [1].

The principle of operation of the acoustic camera system is to record the source of the noise at each level of its acoustics. In the case of an acoustic camera, the level of focus can be changed after the measurement, so it gives the possibility to convert more acoustic images without repeating the measurement. In addition, live preview allows to provide initial measurement results in real time [13].

\section{RESEARCH OBJECT AND SCOPE OF RESEARCH}

The object of the research was autogyro model, called Gyro-One, which is shown in Figure 2. This is an unmanned RC aircraft, which is propelled using $1000 \mathrm{~W}$ electric engine with a maximum take-off weight of about $4 \mathrm{~kg}$. Autogyro is over $1,050 \mathrm{~mm}$ in length and $510 \mathrm{~mm}$ in height. Main rotor diameter is $1,800 \mathrm{~mm}$ [8].

The research was done in a large laboratory room to avoid the effect of sound reflection from the room walls. The measurement was carried out at a constant distance from autogyro of approximately 4 meters. The acoustic camera was used to locate the main sources of noise in the Gyro-One model. Measurement was made during the rotor prerotation as well as during the operation of the main propulsion engine. The obtained results allowed to create a sound pressure level map at the take-off and at a constant cruise speed. 


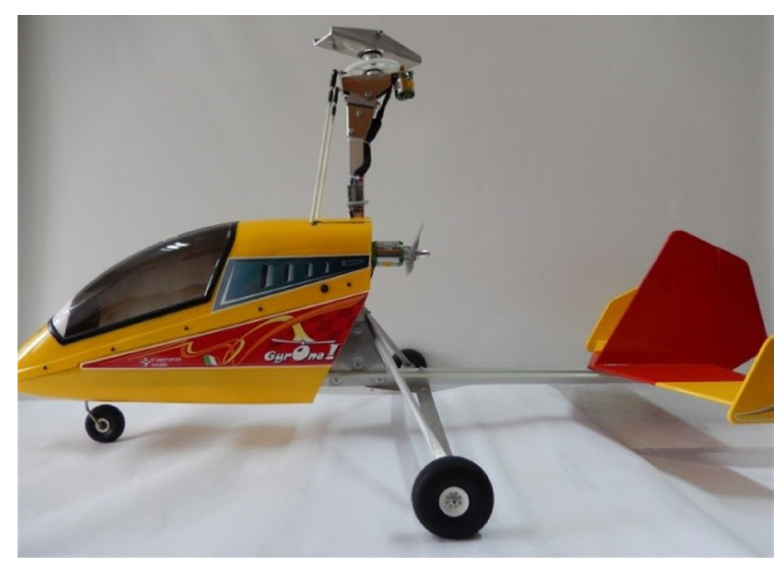

Fig. 2. Autogyro Gyro-One [8]

Table 1. Basic specifications of the autogyro GyroOne [8]

\begin{tabular}{|l|l|}
\hline Engine & Electric, brushless, $1000 \mathrm{~W}$ \\
\hline Battery & LiPo 3S $5000 \mathrm{mAh}$ \\
\hline propeller & $11 \times 7 "$ \\
\hline Main rotor diameter & $1800 \mathrm{~mm}$, \\
\hline Length $x$ height & $1050 \mathrm{~mm} \times 510 \mathrm{~mm}$ \\
\hline Take-off mass & $3-4 \mathrm{~kg}$ \\
\hline Additional & Preroting engine \\
\hline
\end{tabular}

\section{RESEARCH RESULTS}

The research was mainly focused on locating vibroacoustic energy near the research object. From a physical point of view, sound is a mechanical vibration of the gaseous medium, during which the energy is extracted from the source by acoustic waves. The wave propagates in the medium as a result of disruption from the position of the balance of subsequent molecules, what is caused by the transfer of energy. The oscillator causes local compensation of the medium, which propagates at the same frequency as the inducing vibrations and of the same waveform. Taking into account the noise velocity in the air $330 \mathrm{~m} / \mathrm{s}$ (for gas at $273 \mathrm{~K}$, density $1.2933 \mathrm{~kg} / \mathrm{m}^{3}$ and 1000 $\mathrm{hPa}$ ), the wavelength can be determined based on the wave duration (time interval between successive compensations) or frequency. The area in which an acoustic waves spread is called the acoustic field. At each point of the field, the pressure of the medium changes over time, oscillating around the mean value of the static pressure. The difference between the dynamic and static pressure is the acoustic pressure, which is expressed in pascals $(\mathrm{Pa})$. The sound pressure level is the logarithm of the measured pressure ratio $(\mathrm{p} 1)$ to the reference pressure $(\mathrm{p} 0)$, determined by the formula and expressed in decibels $(\mathrm{dB})[14,16]$.

$$
\mathrm{L}_{\mathrm{p}}=10 * \log _{10}\left(\frac{\mathrm{p}_{1}^{2}}{\mathrm{p}_{0}^{2}}\right)
$$

Decibel is a logarithmic unit of measure expressing the proportions between two sizes. Zero sound pressure level occurs when the unknown pressure is equal to the reference pressure, i.e. $20 * 10^{-5} \mathrm{~Pa}$. So $0 \mathrm{~dB}$ does not mean no sound, but only that the measured pressure is equal to the reference pressure and the negative sound pressure level means that the sound wave has a pressure less than the reference pressure.

Taking into account the above, it was decided to fix the object in the position according to the acoustic camera. The array was set at an angle of 90 degrees relative to the main axis of the aircraft. The distance of the measuring array from the rotor rotation axis was $4 \mathrm{~m}$. Figure 3 shows the Gyro-One model at the test bench.

The results of the studies are presented in a form of the distribution of the sound pressure level according to the reference pressure. In order to obtain the pressure maps applied to the image recorded with the HD camera, first, the frequency map as a function of the time generated by the Noise Inspector software has to be analyzed (Figure 4). The first measurement was made during rotor prerotation. Figure 5 shows a map of the pressure distribution generated by the rotating rotor. The maximum value of $54.3 \mathrm{~dB}$ was recorded directly under the autogyro chassis.

The second measurement was made for the main engine operating at maximum speed (Figure 6). The sound pressure distribution on the map changes with zooming in and out of the propeller. The propeller forces the air flow around the aircraft, causing the particles to hit the fuselage

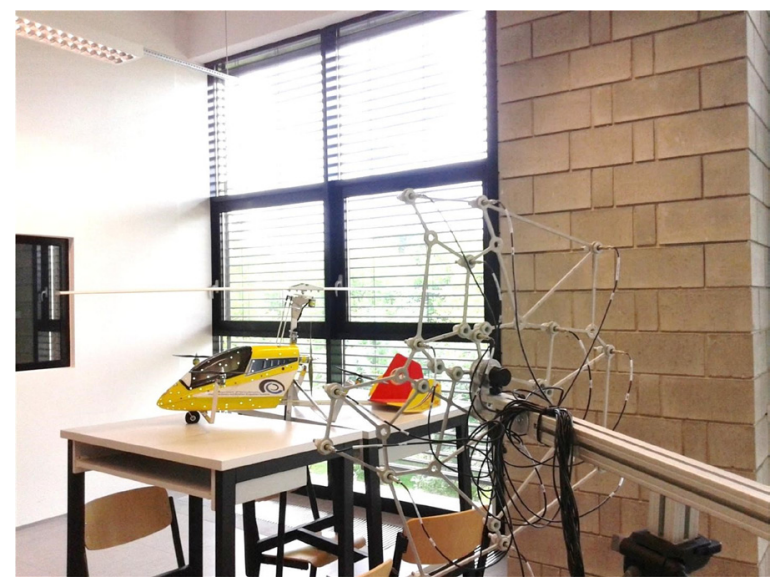

Fig. 3. Research object at the test bench (own study) 


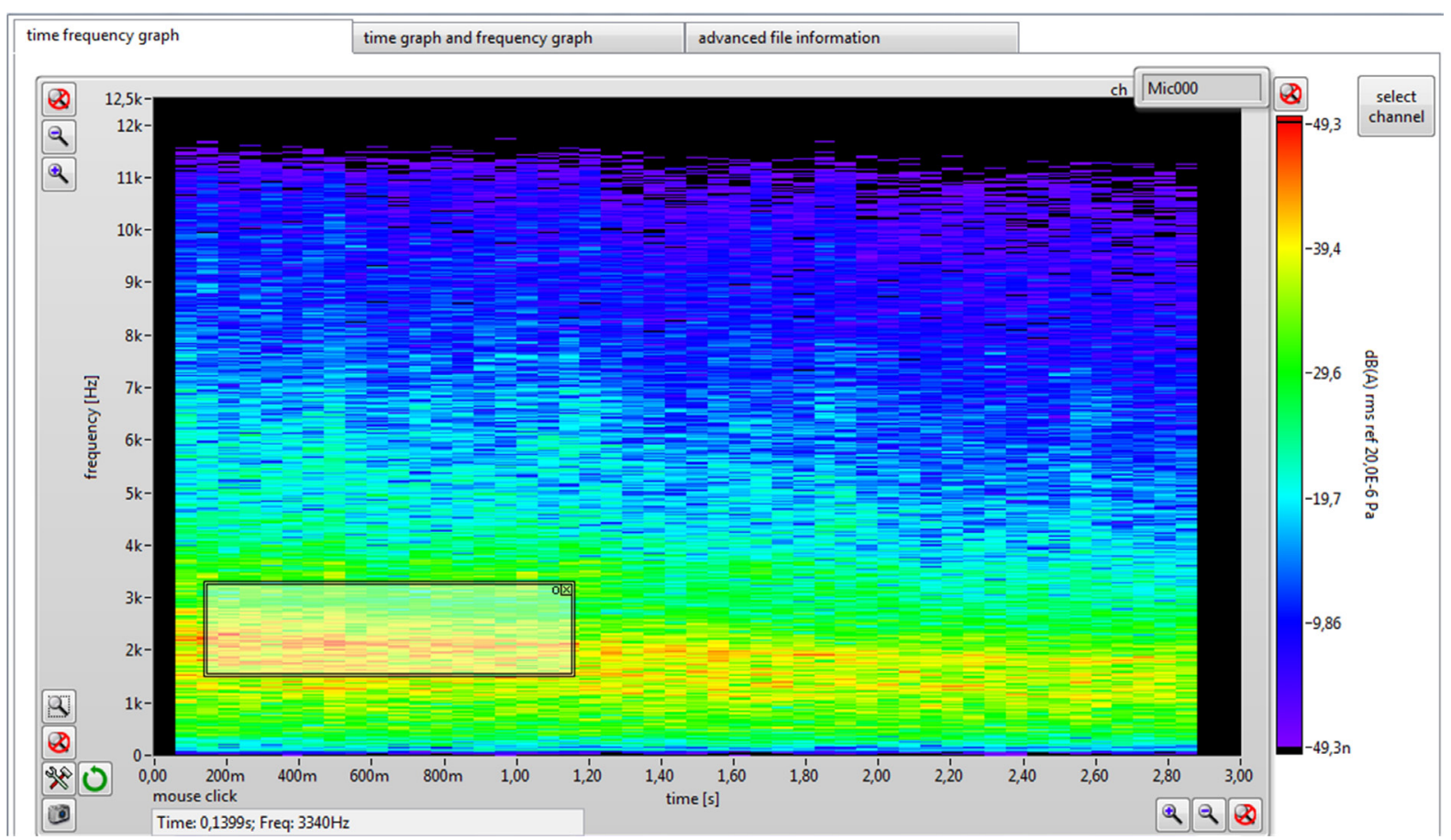

Fig. 4. Frequency map as a function of time generated by Noise Inspector software (own study)

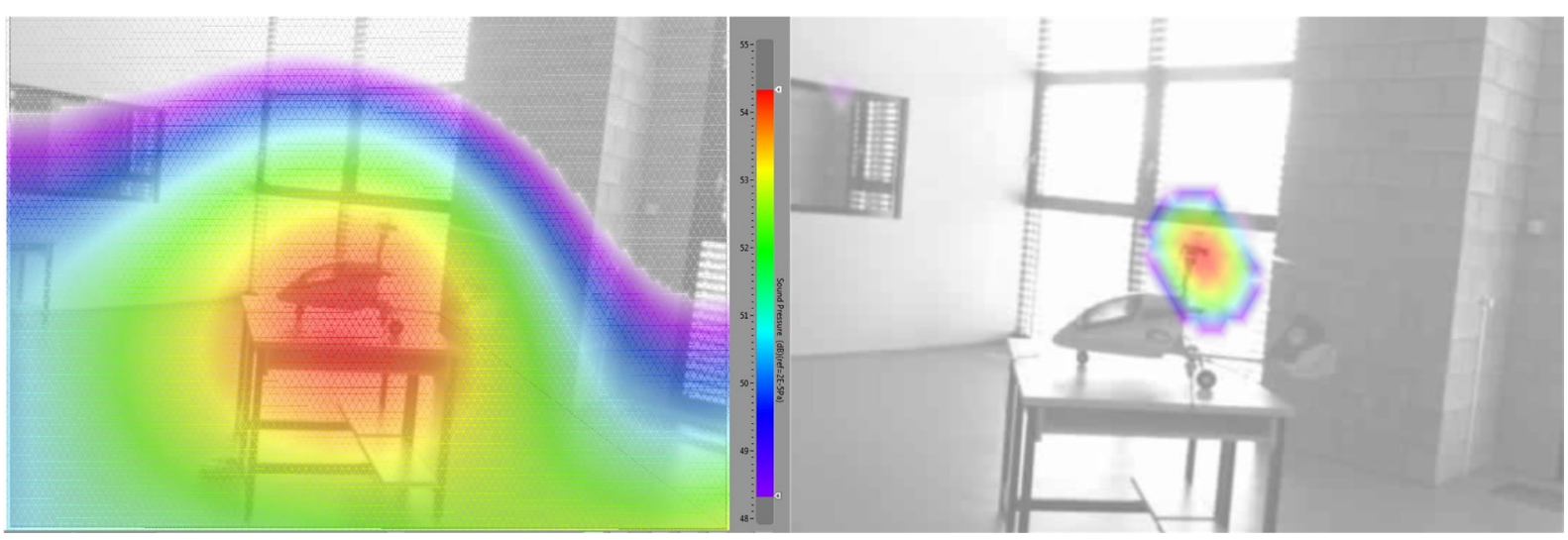

Fig. 5. Map of acoustic pressure levels during rotor prerotation and location of sound source (own study)

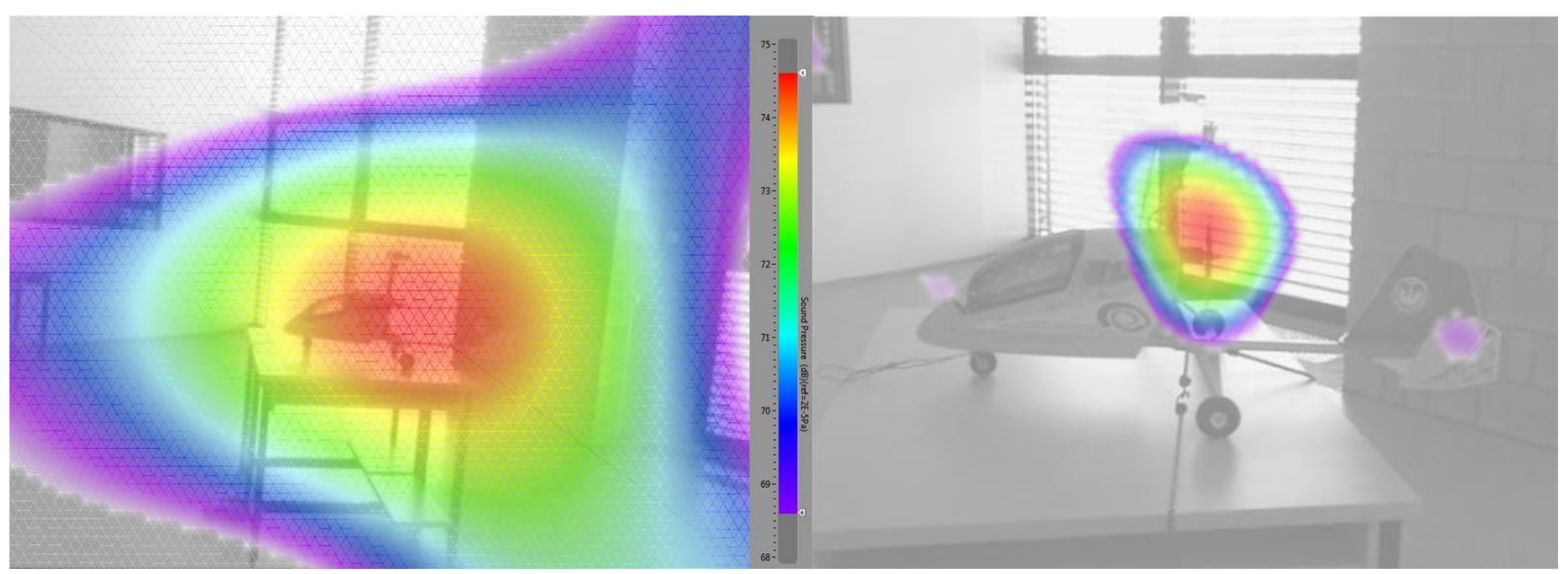

Fig. 6. Map of acoustic pressure levels during main engine rotation and location of sound source (own study) 
and generate an acoustic wave, while behind the engine an increase in pressure and a significant increase in the acoustic field is noticed as the propeller moves away. The maximum value of $74.6 \mathrm{~dB}$ was recorded in the area of the rotating propeller.

\section{SUMMARY}

The advantages of using an acoustic camera used to analyze of noise distribution in relation to aircraft were discussed. Location of noise sources was based on example of autogyro model. The results of the research confirm that the main source of noise in the autogyro is its propeller. In pictures showing the map of acoustic pressure (Figure 5 and 6), it is clear that the main source of noise is occurring near the propeller. The results of the research will be used to construct a new "SafeGyro" aircraft designed to increase the safety of flight, as well as the possibility of vertical takeoff and landing of an autogyro.

\section{Acknowledgement}

Research was funded from the project titled " Stypendia naukowe dla doktorantów pracujących w ramach zespołów badawczych" Program Operacyjny Kapitał Ludzki, priorytet VIII Regionalne kadry gospodarki, Działanie 8.2 Transfer wiedzy, Poddziałanie 8.2.2 Regionalne Strategie Innowacji in the agreement 1565/GI/CP/14.

\section{BIBLIOGRAPHY}

1. Acousticity, Laboratorium rozwojowo- badawcze, http://www.acousticity.pl/laboratorium/wiedza/ kamera-akustyczna.

2. Bauer M., COSMA - Latest Achievements on the Minimisation of Aircraft Noise Annoyance, Greener Aviation Conference, 12-14 March 2014, Brussels, Belgium.

3. Bauer M., Collin D., Iemma U., Janssens K., Márki F. and Müller U., COSMA - A European Approach on Aircraft Noise Annoyance Research. Inter-noise 2014

4. Bauer M., Collin D., Iemma U., Janssens, Márki F., K.,Müller U., COSMA - Community Oriented Solu- tions to minimise Aircraft Noise Annoyance. INTERNOISE 2010, 13-16 June 2010, Lisbon, Portugal.

5. Bauer M., Collin D., Iemma U., Janssens K., Márki F., K.,Müller U., COSMA - Final Report /Publishable Summary, March 2013.

6. Bauer M., Collin D., Iemma U., Janssens, Márki F., K.,Müller U., COSMA - Progress in Community Orientated Solutions to minimise Aircraft Noise Annoyance. Aero-Days 2011, 30 March - 1 April 2011, Madrid, Spain.

7. Cieślak S. Projekt koncepcyjny autożyra nowej generacji o poszerzonych własnościach osiągowych. Praca dyplomowa wykonana pod kierunkiem prof. K. Szumańskiego, Politechnika Lubelska 2010.

8. Czyż Z., Magryta P., Szlachetka M.: Experimental investigation of the impact of flight speed on drag force in the Autogyro model, Advances In Science And Technology-Research Journal, Volume: 9, Issue: 26, Pages: 89-95, 2015.

9. Fiebig W., Wróbel J.: Identyfikacja źródeł hałasu na przykładzie agregatu hydraulicznego. Inżynieria Maszyn, 2014 R. 19, z. 2, 92-98.

10. Fiebig W., Cependa P.: Lokalizacja źródeł hałasu w koparko-ładowarce przy pomocy kamery akustycznej. Zeszyty Naukowe. Mechanika / Politechnika Opolska, 2014, z. 103, 63-65.

11. Intergovernmental Panel on Climate Change (IPCC). Aviation and the Global Atmosphere. www.grida.no./publications/others/ipcc_sr/?src=/ Climate/ipcc/aviation/index.html.

12. International Civil Aviation Organization (ICAO). Environmental report 2010. http://www.icao.int/

13. Kamera akustyczna Noise Inspector dla szybkiej lokalizacji źródeł hałasu. www.wibroakustyka. com.pl.

14. Kirpluk M.: Podstawy akustyki, edycja 2012-11 (popr.2014-08), Warszawa 2012.

15. Malec T.: Pomiary i analiza sygnałów infradźwiękowych generowanych pracą turbin wiatrowych dużych mocy. Praca doktorska, 2015, Politechnika Opolska, Instytut Elektroenergetyki i Energii Odnawialnej.

16. Przedpełska-Bieniek M.: Dźwięk i akustyka. Nauka o dźwięku, Wydawnictwo Sonoria, Warszawa 2011.

17. Teoh L. E., Khoo H. L.: A green fleet planning framework: assessment and improvement strategies. WIT Transactions on Ecology and The Environment, Vol 191, www.witpress.com, ISSN 1743-3541 (on-line), doi:10.2495/SC140621

18. Trumner J., Mundt C., Jet noise analysis of a mixed turbofan engine. Hamburg 2016. 